\title{
Twisting words: does Halakhah really circumvent scripture?
}

\author{
A M I T G VA R Y A H U \\ HEBREW UNIVERSITY, JERU SALEM, IS RAEL
}

A BStRACT A foundational text in the study of Tannaitic Midrash and Halakhah, Sifre Deuteronomy 122 is a list of places where Halakhah 'qpt scripture. This word, ' $q p t$, has long been understood to mean 'circumvent', 'bypass' or 'belie', and the pericope has been read as a list of places where 'Halakhah circumvents scripture', and thus a testament to the power of the accepted tradition to override the words of the Torah. Based on documentary and linguistic evidence, this article questions the interpretation of the word 'qpt and suggests that it means not 'circumvent' but rather 'multiply'. As it does so, it also suggests a new meaning for the list, as a declaration of the limits of the Midrashic method of the Tannaitic school of Rabbi Ishmael, committed both to accepted traditions and to its more restrictive and systematic method of reading scripture.

$\mathrm{T}$ HE RELATIONSHiP between scriptural exegesis and extra-scriptural tradition in rabbinic literature is a central point of debate on the rabbinic movement. Josephus describes the Pharisees as clinging to the 'traditions of the fathers'. The gospels note several extra-scriptural traditions with some derision. In a story in the Babylonian Talmud, Rabbi Akiva attributes laws to Moses which he did not know existed. ${ }^{1}$

Immeasurable thanks go to Hallel Baitner, Dr Idan Dershowitz, Prof. Steven Fraade, Yedidah Koren, Dr Yakir Paz, Prof. Ishay Rosen-Zvi and Dr Assaf Rosen-Zvi for their comments. I am also grateful to Assaf for sharing a chapter of his thesis: Text, Redaction and Hermeneutic in Mekhilta de-Rabbi Ishmael, Tractate Kaspa (Ph.D. thesis, The Hebrew University of Jerusalem, 20I6).

I. The following is a non-representative selection of literature: A.I. Baumgarten, 'The Pharisaic Paradosis', Harvard Theological Review 80:I (1987), pp. 63-77; idem, 'The Name of the Pharisees', Journal of Biblical Literature I02:3 (I983), pp. 4II-28; A. Schremer, “ “[T] He [y] Did Not Read in the Sealed Book": Qumran Halakhic Revolution and the Emergence of Torah Study in Second Temple Judaism', in Historical Perspectives: From the Hasmoneans to Bar Kokhba in Light of the Dead Sea Scrolls (ed. David Goodblatt; Leiden: Brill, 200I), pp. I05-26; P. Mandel, 'Scriptural Exegesis and the Pharisees in Josephus', Journal of Jewish Studies 58:I (2007), pp. 19-32; J. Klawans, Josephus and the Theologies of Ancient Judaism (New York: Oxford University Press, 20I2), pp. 137-80. For a discussion of the story

JOURNAL OF JEWISH STUdies | VOL. LXVIII NO. 2 | AUtUMN $2017 \mid$ pp. 260-83 | ISSN OO22-2097| DOI IO.I8647/3325/JJS-2OI 
A focal text in this debate is a passage in Sifre Deuteronomy that contains a list of places where 'Halakhah "circumvents" scripture'. The reactions to this provocative text have served to demarcate boundaries of religious reforms and mark out positions in scholarship. I believe, however, that the text, as it has been read at least since Rashi's Talmudic commentary (if not since the Babylonian Talmud), is misunderstood: in what follows I offer a revised reading of the text based on a different understanding of the rare verb ' $q p$ which stands at the centre of the statement: not 'cirucumvent' but rather 'double over'.

This revision has implications for our general understanding of the school of Rabbi Ishmael, as well as for the specific problem of the relationship between Midrash and Halakhah in this school. This re-evaluation should serve as a basis for a new line of inquiry on the relationship between tradition and exegesis in Tannaitic literature.

\section{The text}

Sifre Deuteronomy 122 (ed. Finkelstein, I80) is garbled. ${ }^{2}$ A reconstruction yields the following five units:

[I] 'And you shall take the awl', whence to include the thorn and the shard of glass and the sharp edge of a reed? As it says, and you shall take. The words of R. Jose b. Judah.

[2] Rabbi says: 'an awl'. How are awls different? They are made of metal. So too I have nothing but what is made of metal.

[3a] 'And you shall take the awl', do I hear that [it is taken] alone? It teaches, saying 'and his master will present him before the gods', before the judges, to be transferred before those who sold him. ${ }^{3}$

'With an awl' (Exod. 2I:6) - with anything that makes a mark.

[3b] From this Rabbi Ishmael would say: in three places the Halakhah ' $q p t^{\text {' } l}$ scripture. ${ }^{4}$ The Torah says: 'and he shall spill its blood and cover it with

of Rabbi Akiva in bMenah. 29b, see A. Yadin, Scripture and Tradition: Rabbi Akiva and the Triumph of Midrash (Divinations: Rereading Late Ancient Religion; Philadelphia: University of Pennsylvania Press, 20I5), pp. I4I-59 and the literature cited there.

2. The Hebrew text according to MS Vat. Ebr. 32 is appended to this article.

3. The parallel Mekhilta de-Rabbi Ishmael appears more original: śymlyk bmwkryw, 'that he consult with those who sold him' (Mek. RI nezikin 2, ed. Horowitz-Rabin, 252). See also Tg. Ps.-J. ad Exod. 21:6.

4. This is the correct reading of MS Vat. Ebr. 32. MS London BL Add. I6406 (cat. Margoulioth 34I) has ' $w q m t{ }^{'} l$ and Yalkut Shimoni MS Oxford, Heb.b.6 (cat. Neubauer 2637, ed. Heiman p. 3IO) 
earth', and the Halakha says: anything that causes plants to grow. The Torah says 'and he shall write her a book of divorce' and the Halakha says: anything that is detached from the ground. The Torah says 'with an awl', and the Halakha says: with anything. ${ }^{5}$

[4] Rabbi says: [...] 'at the door' and not at the doorpost? Standing. ${ }^{6}$

[5] 'Awl'. This is a large awl.'

This reconstruction has some points that are more disputable than others, and is far from certain. It is clear, however, that the two parts of unit [3], the focus of this article, separated in MS Vat. Ebr. 32 (but not in other MSS of Sifre Deuteronomy), are of the same provenance, and that one leads to the other. Unit [3a] uses the Ishmaelian term shomea ani. It also answers an exegetical question in Deuteronomy by quoting a verse from Exodus, in an exegetical method typical of the Ishmaelian school. Most importantly, unit [3a] ends with a reading of 'an awl' in accordance with the reading attributed to R. Ishmael in [3b]. The introductory phrase 'from this Rabbi Ishmael would say' is intended, here, to be read as a continuation of [3a]. ${ }^{8}$

The programmatic statement 'in three places Halakhah ' $q p t^{\text {' }} l$ scripture' is found in some manuscripts of Sifre Deuteronomy and it is not found in the same place in all the manuscripts that do contain it. ${ }^{9}$ Jacob Nahum Epstein surmised that this is one of the stray pericopae from the Mekhilta to Deuteronomy that found their way into manuscripts of Sifre Deuteronomy, and Louis Finkelsetin marked it thus in his edition of this Midrash. ${ }^{10}$ The

has 'wqpt. The parallel in Midrash Hagadol ad Deut. 24:I has 'wqpt l-. All are simple corruptions of the reading found in MS Vatican.

5. Supply here perhaps 'etc.', referring to the end of [3a].

6. On the ellipsis here, see below n. 93.

7. $m r s c^{c} g d w l$. Cf. $y$ Qidd. I, 59 d. LXX ad Exod. 2 I:6 has a diminutive noun, but perhaps this 'large awl' is similar to 'the large drill' of mKelim I7:I2 and mOhal. 2:3, as opposed to 'the small drill, of the physicians'.

8. This resolves Henshke's contention that the 'awl' case is a later addition to this list. See D. Henshke, 'Le-Ofyo Shel Midrah Ha-Halakhah Ha-Tannai: Shetei Sugiyot', Tarbiz 65:3 (I996), pp. 4I7-38. This was likely the original reading of the Mekhilta as well; see J.N. Epstein, Mevo'ot le-siferut ha-tannaim: mishnah, tosefta $u$-midreshei Halakhah (Tel Aviv and Jerusalem: Dvir and Magnes, 1955), p. 559.

9. For a list of these manuscripts, see ed. Finkelstein ad loc.

Io. L. Finkelstein, 'Prolegomena to an Edition of the Sifre on Deuteronomy', Proceedings of the American Academy for Jewish Research 3 (193I), pp. 3-42 (pp. 26-36); Epstein, Mevo'ot le-siferut ha-tannaim, p. 556; M. Kahana, 'The Halakhic Midrashim', in Sh. Safrai and P.J. Tomson (eds), The Literature of the Sages Part 2 (Compendia rerum iudaicarum ad Novum Testamentum iv; Assen: Van Gorcum, 2006), pp. 3-107, esp. p. 99. Finkelstein, Sifre, p. I80. Passages [3] and [4] are missing in Midrash Hagadol ad Deut I5:I7 (ed. Fisch, p. 342), and the commentary of Ps.-Raabad ad Sifre 
statement is not simply attributed to Rabbi Ishmael, but is part of a work of the school of Rabbi Ishmael. This gives it weight when attempting to articulate the manner in which this school understood the relationship between scripture and Halakhah.

\section{Superseding scripture?}

But what exactly is the relationship between Halakhah and scripture described in this homily? Scholarship has connected this question to the assumed meaning of the participle 'qpt. The primary meaning of this root is 'to go around' or 'to turn':

From his right hand, a firey law for them - when the Word would come out of the mouth of the Holy One, Blessed be He, it would come out through the right side of the the Holy [...] and it would ' $w q p$ the camp of Israel [...] and come back through the right side of Israel to the left side of the Omnipresent.

(Sifre Deuteronomy 343, ed. Finkelstein p. 399)

Similarly, in a more sinister context:

A parable of two dogs who were in the herd and were each other's enemies. A wolf came to take a lamb from the herd, and one of them was fighting him. His fellow said: if I go and help [the wolf] now, he will kill him [the other dog] and then ' $w q p$ ' $l y$ and kill me. They made peace with each other and fought the wolf [together]. (Sifre Numbers, I58, ed. Kahana, 1. 7)

The two dogs in this parable are Moab and Midian, about whom Sifre says 'they had never made peace with each other', but since they both feared Israel, they made peace to fight them. The wolf is thus the Israelites. Midian fear that if they ally with Israel against Moab, Israel will subsequently 'turn on them' or 'double cross them' and defeat them. ${ }^{11}$

Elsewhere, ' $q p$ is used to describe a reading technique, but one that is quite different from the technique described in our text. The following homily,

Deuteronomy I22 (ed. Basser, p. I33). They are found, however, in R. Hillel ad Sifre Deut I22 (ed. Kolidetzky 1948, 45a; 1983, 60b). For more textual evidence, see Henshke, 'Shetei Sugiyot'.

II. Sifre Ba-midbar: mahadurah mevoeret (ed. M. Kahana; Jerusalem: Magnes, 20II), p. I266. See also Sh. Friedman, 'Ha-pitgam ve-shivro: iyyun be-tarbut ha-mashal ba-siferut ha-talmudit', Jewish Studies, an Internet Journal, 2003, pp. 25-82, esp. 8I-2 ; R.K.G. Temple and O. Temple, The Complete Fables (New York: Penguin Books, I998), p. I52. See also Hekhalot Rabatti, II:4: 'w' qpwt wswbbwt 't mlkm'. P. Schäfer, M. Schlüter and H.-G. von Mutius, Synopse zur Hekhalot-Literatur (Texte und Studien zum antiken Judentum 2; Tübingen: Mohr, I98I), sect. I89. 


\section{JOURNAL OF JEWISH STUDIES}

from Leviticus Rabbah, comments on Ps I2:9: 'Around walk the wicked, as vileness is exalted among humankind'.

Around go the wicked etc (Ps. I2:9). R. Judah and R. Nehemiah. R. Judah said: around the wicked, the righteous walk. How so? When the righteous go out of the Garden of Eden and see the wicked being judged in hell, they become happy. [...] R. Nehemiah said to him: be-ribbi, how long will you ' wqp ' lynw the verse? Rather, around the righteous, walk the wicked. ${ }^{12}$

Marc Hirshman noted that this is one of the only places where rabbis actively dispute Aggadic interpretations of a verse. ${ }^{13}$ The exegetical question is if the $r^{r c} y m$ are the subject of the verse (the wicked walk around) or the object (they walk around the wicked). R. Judah holds the latter opinion, and so supplies the subject of the verse: around the wicked, the righteous walk. But R. Nehemiah criticizes him: this is 'turning the verse around', reading it out of order. ${ }^{14} \mathrm{R}$. Nehemiah believes that his own reading is 'straight', not 'crooked'. ${ }^{15}$ Scholarship has tended to connect this meaning of ' $q p$, or its phonetic variant, ' $q b$, to R. Ishmael's statement. ${ }^{16}$ But in Tannaitic Hebrew, the root ' $q p$ does not have this hermeneutic import: a cycle of similar passages in Sifre Deuteronomy uses the root ' $w t$, 'twist', instead. ${ }^{17}$

Second - and more significantly - the relationship of the text and Halakhah in R. Ishmael's statement is different from the one described in Leviticus Rabbah by ' $q p$. In the latter text, R. Judah is accused of assigning different syntactical roles to the words as he wishes. This not what $\mathrm{R}$. Ishmael is referring to. First, it is not R. Judah but 'Halakhah' which is ' wqp ' $l$ the verse. Second, there is no discussion of syntax or even definitions of words: these all stay the same. In R. Ishmael's homily all that changes is that now

I2. Leviticus Rabbah 32:I, ed. Margulies, p. 735.

I3. M. Hirshman, 'Eizehu mekoman shel midreshei ha-agada u-mihem "baalei ha-agada"?', Mehkerei Talmud, C (2005), pp. I90-208, esp. p. 201.

I4. R. Nehemia's criticism is ironic: the verse is about the wicked who 'walk around'. R. Judah says the righteous 'walk around', justifying his exegetical method. R. Nehemiah replies that R. Judah makes the words 'walk around'.

I5. That a verse can be made ' $q b$ and $m^{c} w t$ is likely related to the claim that verses can be made 'straight', i.e. $p \check{s} w t$. . This seems to be the provenance of the term $p s \underline{s} t h d q r^{\prime}$ found in the Babylonian Talmud; see the literature cited by Henshke, 'Shetei Sugiyot', pp. 434-7.

I6. See Sh. Sharvit, 'Hillufei ha-itsurin B-P bi-leshon hakhamim', in M. Bar-Asher and H.A. Cohen (eds), Mas'at Aharon: mehkarim be-lashon mugashim le-aharon dotan (Jerusalem: Mossad Bialik, 2009), pp. 218-43. M. Moreshet, Leksikon ha-po'al she-nithadesh bi-leshon ha-Tana' im (Ramat Gan: Bar Ilan University Press, 197I), p. 268.

I7. See also I. Rosen-Zvi, 'Midrash and Hermeneutic Reflectivity: "Kishmu'o" as a Test Case', in M. Niehoff (ed.), Homer and the Bible in the Eyes of Ancient Interpreters (Leiden: Brill, 2012), pp. 329-44. 
single objects become referents for a class of objects by the same name. The reading of the verse still includes these single objects - they merely stand for more objects than just themselves. ' $q p$ in Leviticus Rabbah and the same word in Sifre Deuteronomy simply do not describe the same reading technique.

\section{Uprooting scripture?}

Another reading of ' $q p$ - or its phonetic variant, ' $q b$ - is 'uprooting'. This definition is found in the Babylonian Talmud, in a sugya on a parallel baraita (b. Sot. I6a), and has had the greatest historical impact. ${ }^{18}$ This context of this sugya is Mishnah Sotah 2:2, which describes the ceremony of testing the wayward wife, based loosely on Numbers $5 .{ }^{19}$ The Mishnah tells that the priest would lift a marble cover and expose the 'dust from the floor of the tabernacle', (Num. 5:I7) to mix with water. The Talmud asks whether only dust ( $\left.{ }^{\mathrm{C}} \mathrm{pr}\right)$ is suitable for this task, or whether ashes ( $\left.{ }^{\prime} \mathrm{pr}\right)$ might be used as well. ${ }^{20}$

One of the proofs the Talmud offers is our baraita, thus:

They asked them: if there is no dust there, can he bring ash? $[\ldots]^{21}$

Come and hear: R. Johanan said in the name of R. Ishmael, in three

places halakhah 'wqbt miqra. Torah said 'with dust', and Halakhah [said]: with anything. Torah said 'bill [of divorce]', and Halakhah said 'with anything'.

Torah said 'a razor', and Halakhah said 'with everything. ${ }^{22}$

I8. Several witnesses of Sifre Deuteronomy, including Yalkut Shim'oni, have the reading 'wqrt $m k r^{\prime}$, which is likely influenced by the Bavli here.

19. On this ceremony, see at length I. Rosen-Zvi, The Mishnaic Sotah Ritual: Temple, Gender and Midrash (trans. O. Scharf; Supplements to the Journal for the Study of Judaism I6o; Leiden: Brill, 2012).

20. ' $p r$ and 'pr are semantically close in Biblical Hebrew; see Gen. 18:27, Job 30:19, Job 42:6. Ezekiel says that mourners 'throw dust on their heads and wallow in ashes' (28:18). In Numbers I9, which describes the 'purification offering' of the red heifer, the ashes ('pr) of the heifer are mixed with water and sprinkled on people who came into contact with dead bodies. Towards the end of the chapter, Numbers instructs: 'and they shall take for the unclean person some of the dust (' $p r$ ) from the fire of cleansing $\left(s\right.$ 'rpt $\left.h h t^{\prime} t\right)$ and fresh water shall be added to them in a vessel'. Clearly this 'dust' means 'ashes', as LXX, Vulgate and Targum Neofiti translate. If 'dust' can mean 'ashes', could 'ashes' perhaps mean 'dust'? See Sifre Numbers I28, ed. Kahana, 1. I, with M. Kahana, Sifre Ba-midbar: mahadurah mevoeret (Jerusalem: Magnes, 2011), p. I065.

2I. Here the Talmud adds a segment, based on a baraita in $6 H u l .84 \mathrm{~b}$, with a hermeneutic dispute between the houses of Shammai and Hillel, on whether 'dust' can also denote 'ashes'. See also Henshke, 'Shetei Sugiyot', pp. 436-8.

22. The identity of this 'razor' is unclear. It may refer to Num. 6:5, discussed below, pp. 276-77. In a genizah fragment (T-S AS 75.126) the baraita reads: 'in three places hlkh ' $w q b t$ mqr'. The Torah said book and Halakhah - with anything. The Torah said, as it is written, and his master shall pierce his ear with an awl, and Halakhah - with anything. The Torah said and he shall cover it with dirt, and Halakhah - with anything.' This reading may be influenced by the Mekhilta to Deuteronomy, or 
And if it is so [that ash can be used instead of dust for the sotah ritual], that too should be counted. $[\ldots]^{23}$

The Talmud counters that the baraita did not include all cases, which makes the proof inconclusive, and attempts to find one more omitted case - that of the shaving of the leper. ${ }^{24}$ Although the Midrashic analysis of Leviticus I4:9 determines that the leper must shave only the places where hair is 'collected together' and 'seen', the law is that the leper is shaved completely, 'like a pumpkin'. This prompts two Amoraim to differentiate between the cases: 'Rav Nahman said: those that were counted are [cases in which] halakhah 'wqbt miqra and this one 'wqbt midrash. ${ }^{25} \mathrm{R}$ av Papa said: those that were counted are halakhah ' $w q b t$ and uproots, and this one ' $w q b t$ and adds. ${ }^{26}$ For Rav Papa, then, the cases in our list, just like those in the parallel Sifre, somehow do the work of 'uprooting' the law. Rashi explains the verb 'wqbt in Bavli Sotah r6a thus: "wqbt. Cuts down his heel, on which he stands. And uproots. ${ }^{27}$

Rashi here has two readings: the first is that ' $q b$ refers to the heel, and that the Halakhah is cutting down the 'heels' of scripture, making it devoid of power. The second, contextually synonymous but etymologically different, is that ' $q b$ is synonymous with ' $q r$, to uproot. ${ }^{28}$

it may simply be a more original version of the baraita. See further M. Kahana, Sifre Ba-midbar, p. 230 n. I3.

23. bSotah I6a, according to MS Oxford, Heb.d.20, Neubauer 2675.

24. It is striking that the Talmud did not use the Halakhah of covering the blood of slaughtered fowl or deer 'with dust' as a comparison.

25. Similarly, the parallel in $\gamma$ Qidd. I (59d) marks the leper as a case in which Halakhah ' wqpt midrash. The reading of the verse according to R. Ishmael's method yields a certain result; Halakhah accepts that result and then goes beyond it - but does not negate it. Shaving 'like a pumpkin' includes, of course, all those places where hair is 'clumped together and seen' as well as those where it is not. See also M. Chernick, 'The Formal Development of Kelal U-Ferat Ukelal', Tarbiz 52:3 (1983), pp. 393-4IO, esp. p. 403.

26. On the relationship between the Bavli baraita and the Sifre, cf. Henshke, 'Shetei Sugiyot'. It seems sounder to assume the primacy of the Tannaitic version (in a Genizah Fragment, T-S AS 72.I2, Rav Papa's statement reads: 'and this one 'wqpt midrash and adds'. This might be a corruption based on the end of the previous statement, but might also be an expansion of that statement).

27. See also Rashi ad Job 37:4, with N. Netzer, 'Mekomah Shel Leshon-Hakhamim Be-Farshanuto Shel Rashi La-Mikra', in Zvi Steinfeld (ed.), Rashi: Iyyunim Be-Yetsirato (Ramat Gan: Bar Ilan University Press, 1993), p. I07.

28. Later on this folio, s.v. amar rav nahman, Rashi seems to say that 'Halakhah ' $w q b t$ - adds to scripture'. As noted by Joel Sirkis, the author of Bayit Hadash, in his emendations ad loc., this reading is garbled, and should be emended, perhaps as per his suggestion. 
This approach, that the rabbis believed that they had the power to 'override', 'circumvent' and 'uproot' scripture, was adopted by Nachman Krochmal in his More Nevukhe Ha-zeman:

And for this purpose [of expounding the Torah] was introduced (nithadesh) another contradiction: miqra and halakhah: the verse (miqra) which is the support and which is expounded for the sake of learning it (nidrash le-talmudo) and the Halakhah, which relies on it and which is learned from it. [...] and they said further: in three places halakhah 'qbt miqra, and these words are irregular, and so likely early (kadmon) and its explanation is as if the Halakhah will trample $\left(t a^{c} a k o v\right)$ the verse and harass it so that it expresses the opposite of what is explicated in it. ${ }^{29}$

Students of midrash adopted this reading almost unanimously. ${ }^{30}$ Azzan Yadin-Israel is the most recent of a long line of readers who typified this relationship as a conflict: 'This passage teaches that the conflict between the scriptural injunction and the ultimate ruling of the halakhah was, for Rabbi Ishmael, one of three instances in which halakhah bypasses scripture. ${ }^{31}$ David Henshke similarly notes that 'Rabbi Ishmael intended here only to state that in three places we are in possession of a Halakhah to Moses from Sinai, without any Midrashic connection to scripture, that stands in contradiction to scripture' (428; my translation). ${ }^{32}$

29. Krochmal, More nevukhe ha-zeman (Lemberg, I85I), I85a-b. On Krochmal, see J.M. Harris, Nachman Krochmal : Guiding the Perplexed of the Modern Age (Modern Jewish Masters Series 4; New York: New York University Press, 1991).

30. Krochmal is echoing Rashbam ad Exod. 2I:I as well as Elijah of Vilna, Aderet Eliyahu (Vilnius, I87I) ad Exod. 21:6. See also A.J. Heschel, Heavenly Torah: As Refracted Through the Generations (trans. G. Tucker; London: Continuum, 2005), p. 53; P. Heger, The Pluralistic Halakhah: Legal Innovations in the Late Second Commonwealth and Rabbinic Periods (Berlin: Walter de Gruyter, 2003), pp. 64-6; S. Fraade, Legal Fictions: Studies of Law and Narrative in the Discursive Worlds of Ancient Jewish Sectarians and Sages (Leiden: Brill, 20II), p. 437; E.E. Urbach, ha-Halakhah, mekoroteha ye-hitpathutah (Yad la-Talmud; Ramat-Gan: Masadah, I984), p. 8. On the Vilna Gaon's reading here, see J.M. Harris, How Do We Know This?: Midrash and the Fragmentation of Modern Judaism (Albany NY: SUNY Press, 1995), pp. $235^{-9}$ and the literature discussed.

3I. A. Yadin, Scripture as Logos: Rabbi Ishmael and the Origins of Midrash (Divinations: Rereading Late Ancient Religion; Philadelphia: University of Pennsylvania Press, 2004), p. I43. The translation 'bypass' reads it like Modern Hebrew ' $q p$.

32. Yadin and Henshke emphasize their differences: see A. Yadin, '4QMMT, Rabbi Ishmael, and the Origins of Legal Midrash', Dead Sea Discoveries I0:I (2003), pp. I30-49, esp. pp. I33-7; Yadin, Scripture as Logos, pp. I42-6; A. Yadin, 'Resistance to Midrash? Midrash and Halakhah in the Halakhic Midrashim', in C. Bakhos (ed.), Current Trends in the Study of Midrash (Leiden: Brill, 2006), pp. 35-58, 4I-2; Henshke, 'Shetei Sugiyot', pp. 427-34; D. Henshke, Simhat Ha-Regel Be-Talmudam Shel Tana' im (Jerusalem: Magnes, 2007), p. 8 n. 38. Both share the conviction that ' $q p$ means 'contradict' or 'circumvent'. See, however, Yadin, Scripture and Tradition, p. 278 n. 70. There, he observes that this reading of ' $q p$ does not accord with the examples offered: 'all three are inclusion derashot that expand the scope of the scriptural injunction'. But Yadin does not flesh out the implications of this 
Furthermore, as Rav Papa explains, these three cases are special, because in them the Halakhah ' $w q m t w^{c} w q r t$ circumvents and uproots, whereas in the case of the leper Halakhah 'circumvents and adds'. This characterization, quoted by Rashi, above, has had even further significance in obfuscating the true meaning of the homily. Modern English translations of Sifre have similarly used 'circumvent' for ' $q p t^{33}$

' $q r$ is regularly used by Tannaim as opposed to $q y m$, 'to uphold'. ${ }^{34}$ 'Upholding the words of the Torah' is a scriptural imperative (Deut. 8:18, 27:26), ${ }^{35}$ and rabbinic literature uses the verb ' $q r$ to signify the opposite of observing the commandments properly. For example:

Akiva, you have uprooted ('qrth) what is written in the Torah, 'at twilight', 'at its appointed time', whether on a weekday or on the Sabbath (m. Pes. 6:2) ${ }^{36}$

observation: if they are derashot, then why does R. Ishmael ascribe them to Halakhah? Are these really the only cases in which $\mathrm{R}$. Ishmael is willing to cede authority to extra-scriptural tradition? Did R. Ishmael, for example, believe that hands should not be washed before eating, or that a candle should not be lit on the eve of the Sabbath? Yadin's critique of Henshke is certainly correct, but does not go far enough. See also the essentially similar reading of Z.A. Yehudah, The Two Mekhiltot on the Hebrew Slave (Ph.D. thesis, Yeshiva University, 1974), pp. 422-5; M. Katz, Talmud Yerushalmi massekhet kiddushin: mahadurah u-bi'ur katsar (Jerusalem: Yad Itzhak Ben-Zvi, 20I6), pp. I09-I4. For these last two references I thank Assaf Rosen-Zvi. See the discussion in idem, Text, Redaction and Hermeneutic, ch. 4 n. I 10.

33. R. Hammer, Sifre: A Tannaitic Commentary on the Book of Deuteronomy (Yale Judaica Series 24; New Haven CT: Yale University Press, 1986), p. I67 and ibid. n. 4; H.W. Guggenheimer, The Jerusalem Talmud: Third Order: Našim, Tractate Qiddušin (Studia Judaica; Berlin: Walter de Gruyter, 2008), p. 85. J. Neusner, Sifre to Deuteronomy: An Analytical Translation (Brown Judaic Studies 98, IoI; Atlanta GA: Scholars Press, 1987) does not translate our passage; J. Neusner, The Talmud of the Land of Israel: A Preliminary Translation and Explanation (Chicago Studies in the History of Judaism; Chicago: University of Chicago Press, I994, I982), vol. 26, p. 52, uses 'supersede'. T. Martínez Sáiz and E. Cortès, Sifre deuteronomio: comentario tannaítico al libro del Deuteronomio (Collectània Sant Pacià no. 40, 60; Barcelona: Facultat de Teología de Catalunya, I988), p. I22, offer 'remplaza', to replace or supersede. Qiddushin: Antrauung (trans. H.-P. Tilly; Übersetzung des Talmud Yerushalmi; Tübingen: Mohr, I995), III/7, p. 59, has 'verdrängt', to suppress. M. Schwab, Le Talmud du Jerusalem (Paris: Maisonneuve, I933), p. 215, has 'En trois cas (seulement), l'explication doctrinale est contraire au texte de la Tora (Pentateuque)' (emphasis mine). The Soncino translation of bSotah I6a (London: Soncino, 1985) has 'crushes the Scriptural text under heel', explaining in a note (7): 'i.e. practice goes beyond the letter of the Torah'. The Artscroll translation (Brooklyn: Artscroll Masorah, 200o), p. I6a', has 'undermines the verse' as the literal translation, 'overrides the simple meaning of the verse' as the interpretive translation, and in a note (8) explains: 'the basic meaning of the verse ... is negated by the halachah'.

34. See e.g. mTer. 2:3.

35. In rabbinic literature, 'upholding' words of Torah can also mean to engage or to give an account of a certain verse or pericope in the Torah. Thus we see, e.g., the term $m$ ' ' ny mqyym - not 'how do I observe', but rather 'how do I give an exegetical account' for a certain verse. Giving an exegetical account for a verse also involves marking out its practical implications.

36. See also $m H$ Hor. I:3 for an equivalency of $l^{c} q w r$ and $l b t l$. 
Rav Papa's reading of the Tannaitic tradition in Bavli Sotah I6a, then, is that in Rabbi Ishmael's three examples scripture was similarly being 'uprooted'. It would have been the first time a rabbi would have said unapologetically that the rabbinic tradition was capable of actively legislating against scripture. ${ }^{37}$

\section{The crux}

But neither meaning of ' $q p /^{c} q b$ can adequately account for the relationship between Halakhah and scripture described in R. Ishmael's homily. ${ }^{38}$ Scholars have noted that the examples in R. Ishmael's tradition do not 'uproot' scripture. Foremost among them is a Tosafistic note, found in Rashi ad Sotah I6a: ${ }^{39}$

But if you should say (ve-im tomar) that it does not uproot but rather adds to scripture, indeed (ibera) ${ }^{40}$ it is uprooting, for he is lashed for it [transgressing the commandment $]$ and it is forbidden to beat Israel for naught $[\ldots]$

This answer, clever as it is, hardly masks the crux of the question: 'it does not uproot, but rather adds to scripture'. The three examples in R. Ishmael's homily do not demonstrate that Halakhah does not allow the use of awls, bills and earth for their respective uses but rather that Halakhah expands the verses and reads each of these objects as a category of objects: things that make impressions on the body, things that are detached from the ground, and things upon which plants might grow.

Cana Werman offers what is in my opinion the best characterization of the relationship between Halakhah and scripture in this passage: ' $R$. Ishmael presumes the existence of Halakhah that "circumvents" scripture; that is, the Halakhah accords with the details in the Bible, but expands it

37. Ideas like this appear elsewhere in rabbinic literature; see e.g. bMak. 22b (attributed to Rava in ed. Princ, MS Munich 95, T-S FI(I).26, and to Abaye in MS Jerusalem Herzog I).

38. Parallels in both Sifre Deut. and $\gamma$ Qidd. read 'qpt, while all Bavli witnesses read ' $q b t$. This is a phonetic variant: the fact that both Palestinian sources independently read 'qpt makes it likely that this is the more original reading. See Sharvit, 'Hillufei ha-itsurin B-P bi-leshon hakhamim'; Moreshet, Leksikon, p. 268.

39. The note uses the Tosafistic phrases ve-im tomar and ve-yesh lomar. The textual tradition of Rashi's commentary on bSotah has not been described adequately and there are no complete manuscripts to consult.

40. For the definition and etymology of this word, see M. Sokoloff, A Dictionary of Jewish Babylonian Aramaic of the Talmudic and Geonic Periods (Ramat-Gan: Bar Ilan University Press, 2002), p. Iogb. 
and permits additional details. ${ }^{41}$ In this, she follows David Weiss Halivni, who emphatically disassociated our passage from his central question of peshat and derash: 'it is a case of adding to the plain meaning while preserving the latter ... the statement is basically saying that in these three instances one does not have to follow the letter of the Law. Something similar in nature is adequate - though not preferable. ${ }^{42}$ Assaf Rosen-Zvi has similarly used Modern Hebrew sheker, 'a lie', to explain ' $q p$ while pointing to this feature. ${ }^{43}$ Aside from the strained explanation for the English word 'circumvent', or the Hebrew sheker, this is an accurate portrayal of the relationship between law and scripture in Sifre Deuteronomy I2I. Azzan Yadin-Israel also noted that these examples do not contradict scripture at all: 'All three are inclusion derashot that expand the scope of the scriptural injunction ... and are not incompatible with or contrary to scripture' (279 n.70). But if these examples are 'derashot' - that is, based on a reading of the verse - why are they 'the only three instances in which extra-scriptural tradition serves as an independent source of legal authority' (197)? Even grammatically, the content of the 'Halakhah' cannot stand alone as a source of legal authority. The clauses attributed to 'Halakhah' are devoid of a subject and a predicate, and are syntactically dependent on the language of the verse for them to have any meaning. Thus, the verse says: 'and his master should pierce his ear with an awl', and only after reading the verse can the Halakhah replace 'awl' with 'anything that makes an impression'. This is not how an independent source of legal authority would make a statement, and not how the Mishnah, the pre-eminent source of halakhot in rabbinic culture, makes its statements.

\section{The reading method}

The examples of 'Halakhah 'qpt scripture' that R. Ishmael introduces are not instances of an extra-scriptural tradition, unrelated to scripture. 'Pharisaic' traditions, such as purification of the hands or lighting a candle on the Sabbath

\footnotetext{
4I. C. Werman, 'Oral Torah vs. Written Torah(s): Competing Claims to Authority', in Rabbinic Perspectives: Rabbinic Literature and the Dead Sea Scrolls. Proceedings of the Eighth International Symposium of the Orion Center for the Study of the Dead Sea Scrolls and Associated Literature, ed. S. Fraade, A. Shemesh and R. Clements, STDJ, LXII (Leiden: Brill, 2006), pp. I75-97, I92.

42. D.W. Halivni, Peshat and Derash: Plain and Applied Meaning in Rabbinic Exegesis (New York: Oxford University Press, 1998), p. 198 n. 63.

43. Rosen-Zvi, Text, Redaction and Hermeneutic, ch. 4.
} 
eve, are not the subject of these three statements. ${ }^{44}$ While we do not know whether R. Ishmael espoused these traditions, it is plausible that if he did not he would not have been part of the rabbinic millieu such as it was in the second century CE. R. Ishmael's use of 'Halakhah' here is somewhere between 'a tradition on certain procedures based on scripture' and 'an authoritative interpretation of scripture'.

Assaf Rosen-Zvi has demonstrated that the laws that $\mathrm{R}$. Ishmael attributes to Halakhah are, in the parallel Akivan Midrashim, derived directly from scripture. ${ }^{45}$ A good example of this is found in our homily:

Sifre

'And you shall take the awl', whence to include the thorn and the shard of glass and the sharp edge of a reed? As it says, and you shall take. The words of $\mathrm{R}$. Jose $\mathrm{b}$. Judah.

Rabbi says: 'an awl'. How are awls different? They are made of metal. So too I have nothing but what is made of metal.

\begin{abstract}
Mekhilta
'With an awl' (Exod. 2r:6) - with anything that makes a mark.

From this Rabbi Ishmael would say: in three places the Halakhah 'qpt ' $\%$ scripture. The Torah says: 'and he shall spill its blood and cover it with earth', and the Halakhah says: anything that causes plants to grow. The Torah says 'and he shall write her a book of divorce' and the Halakhah says: anything that is detached from the ground. The Torah says 'with an awl', and the Halakhah says: with anything.
\end{abstract}

Rabbi Jose b. Judah reads the verb and you shall take as inclusive of any sharp thing, while Rabbi reads the awl as an example. Neither makes recourse to Halakhah; instead they focus on the inclusivity of the verb 'you shall take', to include everything (everything sharp or everything made of metal). This, Rosen-Zvi persuasively argues, is the proper Akivan way of doing things. ${ }^{46}$ The basic unit of meaning in the Akivan Midrashim is a

\footnotetext{
44. On these traditions, see Baumgarten, 'The Pharisaic Paradosis'. For a detailed examination of one such insitution, see Y. Furstenberg, 'Defilement Penetrating the Body: A New Understanding of Contamination in Mark 7.I5', New Testament Studies 54:02 (2008), pp. 176-200.

45. Rosen-Zvi, Text, Redaction and Hermeneutic, ch. 4, sect. B.

46. Rosen-Zvi calls these homilies 'truncating homilies' (derashot qitu'a) because they truncate the verse and expound the truncated version. For a comprehensive list of these homilies, see Rosen-Zvi, Text, Redaction and Hermeneutic, ch. 4, Appendix B.
} 
sentence which consists of only a subject and predicate. Anything beyond this can be expounded. ${ }^{47}$

Both schools thus share the accepted tradition on the practical implications of the verses in question, and differ only on the question of the method in which these norms are derived from scripture. The Akivans derive this information from scripture 'itself', while the Ishmaelians relegate it to 'Halakhah'. This intimates that R. Ishmael's statement reflects a general validation of halakhot as binding interpretations of the verse. While usually their content can be derived from scripture, in a handful of cases he states that it is impossible. The more complex reading method of the school of $\mathrm{R}$. Akiva is able to do so with ease. This list is thus a testament to the limits of the Ishmaelian exegetical method, based on rules and exegetical terminology. 'Halakhah' here is not so much an 'extra-legal tradition', but what might be termed an 'extra-exegetical reading tradition'. ${ }^{48}$ It is not exegetical in the sense that it does not conform with the rules of the school, but it is most clearly a reading of the verse: it notes details in the verse and explains them while expanding their accepted meaning. This tradition is recognized by the school of R. Ishmael as authoritative in the application - if not the explication - of scripture.

Reading a detail in a scripture as an example for a category of things is an accepted technique both within and outside of rabbinic literature. ${ }^{49}$ Plutarch described this method for use in reading epic:

Chrysippus has rightly indicated how the poet's statements can be given a wider application, saying that what is serviceable should be taken over and made to apply to like situations. For when Hesiod says, 'Nor would even an ox disappear were there not a bad neighbour, ${ }^{50}$ he says the same thing also about a dog and about an ass and about all things which in a similar way can 'disappear. ${ }^{51}$

47. Oral communication with Prof. Shlomo Naeh. See A. Gvaryahu, 'A. Gvaryahu on A. Yadin-Israel "Scripture and Tradition: Rabbi Akiva and the Triumph of Midrash", The Talmud Blog https://thetalmudblog.wordpress.com/2015/02/23/a-gvaryahu-on-a-yadin-israel-scripture-andtradition-rabbi-akiva-and-the-triumph-of-midrash; accessed ro July 2017.

48. On the tradition of the fathers, see Baumgarten, 'The Pharisaic Paradosis'.

49. See the explication of the rule in Baraita di-sheloshim u-shtayim middot, ed. Enelow, p. $3 \mathrm{I}$.

50. Hesiod, Works and Days, 1. 348.

5I. Plutarch, Quomodo adolescens poetas audire debeat $\mathrm{I} 3, L C L$, p. I80. 
This method is employed in the school of R. Ishmael, but only through the use of hermeneutical rules and markers. ${ }^{52}$ There are three terms Ishmaelian Midrashim use to implement this rule: $k l d b r$, 'anything'; $m k l m q w m$, 'in any event'; and dbr hktwb bhwwh, 'scripture speaks of things that are'. None of these terms is effective in the three cases in our tradition, as the following short survey will show.

\section{$K l d b r$}

The Ishmaelian homilist does not use the term $k l d b r$, 'anything', except when he can show that scripture itself intends it by employing an intertext or noting a peculiarity in the verse. For example:

And one smite the other with a stone or with his fist (Exod. 2I:I8). This is to declare that one is guilty if he smites with either one of them. With a stone or with his fist. This is to tell that a stone and the fist are merely types of instruments capable of producing death. You say it comes to teach this. Perhaps however it only comes to teach that if he smote him with a stone or with his fist he is guilty, but if he smite him with any other thing $[k l d b r]$ he is not guilty? It teaches to say: And if he smote him with a stone in the hand, whereby a man may die, and he died, he is a murderer, etc. (Num. 35:I7) $)^{53}$

Exodus 2I:I8-I9 is a short pericope about a man who fought another man, hitting him 'with a stone or with his fist', but not killing him. The Mekhilta understands that this means that usually stones and fists are capable of killing, so perhaps only blows with stones and fists should make a person liable for murder? Not so, says the Mekhilta, because Numbers 35:17 says explicitly that a man is a murderer for killing with 'a stone in the hand, whereby a man may die'. The Midrash reads this clause as including a specific clause, the stone, and a general one, to include any other object that might cause the death of a person. This case is similar to the three cases in Sifre: there is a detail explicated in scripture and a Midrashic source explains that the detail refers to a class of things with the same property, not only that detail. But there are two important differences: first, the cases in the baraita are prescriptive, while the case here is descriptive. And, second, here there is another verse that contains the required information. ${ }^{54}$

52. See the discussion in Rosen-Zvi, Text, Redaction and Hermeneutic, ch. 4, sect. B.

53. Mek. RI nezikin 6, ed. Horowitz-Rabin, p. 269, trans. Lauterbach, pp. 390-I.

54. See also the parallel Mek. RS, ed. Epstein-Melammed, p. I74: 'with a stone or with a fist. I 


\section{JOURNAL OF JEWISH STUDIES}

Another example, this time from two Akivan sources, is the following:

He who constrains a millstone transgresses a negative commandment and is liable for both vessels (the upper and lower stones.) As it says do not take a mill or an upper millstone in pledge.

And they said not only a millstone, but anything used for life-sustaining food, as it says for that would be taking a life in pledge (m. Bab. Mes. 9:I3).
Do not take a mill or an upper millstone in pledge (Deut. 24:6).

I only have the specific 'mill' and 'upper millstone'. Whence to include anything, as it says for that would be taking a life in pledge.

If so, why does it say mill or an upper millstone? As the mill and the upper millstone are special in that they are two implements who perform one task, and he is liable for each one independently, so too any two implements which perform one task - he is liable for each independently (Sifre Deut. 272, ed Finkelstein, 292)..$^{54}$

Both these texts discuss the law in Deuteronomy 24:6 forbidding a creditor to constrain a 'mill or upper millstone, for they would be taking a life in pledge'. This verse is read as forbidding not only taking the two parts of a millstone as a pledge, but also other tools. For the Mishnah, this includes only tools involved in the production of 'life-giving food', ('kl nps'), but for Sifre this includes 'anything' $(k l d b r) .{ }^{56}$ 'Taking a life in pledge' is read as the general rule, and marks the mill and the upper millstone as examples for a class of objects. Objects which make food (as in Mishnah), or any object, to the inclusion of objects with only function as part of a pair (as in Sifre). ${ }^{57}$

\footnotetext{
have only the specific "stone" and "fist", whence to include everything else? It teaches to say: and the assailant shall be free of liability (Exod. 21:19), with anything.' For the Akivan Mekhilta de-Rabbi Simon the appearance of the participle $m k h$ is sufficient to include all manner of blows, but not for the Ishmaelian Mekhilta de-Rabbi Ishmael. For a similar relationship, compare Sifre Num. I6o with Sifre Zuta ad Num. 35:16-334. The details derived from a comparison of verses in the Ishmaelian Sifre are read into each verse in the Akivan Sifre Zuta.

55. See the examples in $t B . M e s i^{c} a$ Io:II.

56. Cf. the dispute between Rabbi and R. Jose b. Judah on whether the ear of the slave can be pierced by any object or just a metal object.

57. Sifre here is reflected in $t B$. Meși ${ }^{c} a$ Io:II, which discusses distraining scissors and pairs of cows. For parallels and medieval commentaries which try to harmonize Tosefta and Mishnah, see S. Lieberman, Tosefta Ki-Feshuțah: Be ur Arokh La-Tosefta (New York: Jewish Theological Seminary of America, 1955), vol. 9, p. 302.
} 
The parallel Ishmaelian Midrash, reconstructed by David Zvi Hoffmann in Midrash Tannaim, reads:

Do not constrain a mill or an upper millstone - why was this said? For it says if you constrain the garment of your fellow (Exod. 22:25), could I hear that this includes the mill and the upper millstone? It teaches, saying: do not constrain a mill or an upper millstone. If he had five mills and he only needs one of them, I hear ${ }^{58}$ that he may constrain any of them. For it teaches, saying: ${ }^{59}$ for that would be taking a life in pledge - I said naught but things which are used to make life-sustaining food. ${ }^{60}$

The homilies in Midrash Tannaim are reconstructed from the thirteenthcentury Midrash Hagadol, a Yemenite Midrashic anthology which does not cite its sources. But the Ishmaelian terminology here makes clear that these homilies are quoted from the lost Mekhilta Deuteronomy. ${ }^{61}$ The term why was this said, for it says (lmh n'mr, lpy šhw' 'wmr) connects Deuteronomy 24:6 to Exodus 22:25, reading them together to state thus:

Pawning is lawful if you return the distrained object at nightfall (Exod. 22:25).

However, taking a mill or an upper millstone in pledge is forbidden in any case, because that would be taking a life in pledge (Deut 24:6).

The homilist goes on to explain that if a person has several millstones, ${ }^{62}$ then they may be distrained, because the prohibition on distraining mills is only those which make life-sustaining food. ${ }^{63}$

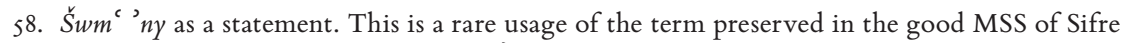
Numbers. See M. Kahana, Akdamot Le-Hotsa' ah Hadashah Shel Sifre Ba-Midbar (Ph.D. thesis, Hebrew University of Jerusalem, I982), pp. I66-9.

59. Tlmwd lwmr in a supporting sense. This is a rare usage of the term preserved in good textual witnesses of the Tannaitic Midrashim; see M. Kahana, Akdamot Le-Hotsa'ah Hadashah Shel Sifre Ba-Midbar, p. I73; L.E. Bar-Levav, Ha-Mekhilta de-Rabi Yishma'el 'al-pi 'otek me' uleh min ha-genizah (M.A. thesis, Hebrew University of Jerusalem, 1997), p. 91 n. 397; idem, Mekhilta de-Rashbi parashat Nezikin (Jerusalem: Magnes, 20I3), p. I20.

6o. D.Z. Hoffmann, Midrasch Tannaim zum Deuteronomium aus der in der Koeniglichen Bibliothek $z u$ Berlin befindlichen Handschrift des 'Midrasch haggodol' Gesammelt und mit anmerkunfen versehen Nebst mehreren beilagen (Berlin: H. Itzkowski \& M. Popelauer, I908), p. I56. Cf. the parallel $t B$. Meși ${ }^{c} a$ IO:II: 'if he had five mills he is not allowed to distrain even one of them. But if he only works with [a certain] one of them, he is liable only for that one.'

6I. See nn. 58-9 above. Reading these terms in their rarer senses resolves the interpretive issues and corrections raised by Lieberman, Tosefta Ki-Feshutah, vol. 9, p. 303; Hoffmann, Midrasch Tannaim Zum Deuteronomium, p. I56.

62. 'Five' denotes 'some'. See T. Novick, 'Crafting Legal Language: "Four or Five” in the Mishnah and the Tosefta', Jewish Quarterly Review 98:3 (2008), pp. 289-304.

63. The Mishnah quoted above is a conflation of both Ishmaelian and Akivan traditions, adopting the qualification 'things which are used to make life-sustaining food' from Mekhilta Deuteronomy. 


\section{JOURNAL OF JEWISH STUDIES}

\section{$M k l m q w m^{64}$}

This term is used to cancel a restriction or detail found in a scriptural verse, by citing a verse which does not contain that same restriction. For example:

$<$ And the Lord spoke to Moses etc. Sanctify to me all the first born etc. $>$ It is mine (Exod. I3:I). Why is this said? Because when it says all the firstling males you shall sanctify to the Lord your God (Deut. I5:I9) - consecrate to receive reward. Or perhaps, if you consecrate it, it becomes consecrated, and if not it does not? It teaches, saying it is mine - in any event (Mek. RI pisha I6, ed. Horowitz-Rabin, 58).

Deuteronomy demands that first borns be 'consecrated' to God, which the Mekhilta reads as demanding a formal act. Exodus states they already belong to God. The apparent contradiction is resolved by stating that Deuteronomy's requirement does not effect consecration but is a separate commandment to name the consecrated object as such. The homilist reads Exodus as a general description - 'it is mine - in any event' - and subordinates the specific commandment in Deuteronomy to this description. Without the additional verse in Exodus, the suggested reading in Deuteronomy would stand, and a formal act of consecration would be required for firstborns.

Another example can be found in Sifre Numbers: ${ }^{65}$

A razor shall not touch his head (Num. 6:5) - I have naught but a razor. If he plucked, singed $(s p s p)^{66}$ and cut [with scissors], whence [do I know] that he is lashed forty [lashes]? It teaches, saying: he shall be holy - in any event. The words of R. Josiah. R. Jonathan says: scripture is speaking of a razor, thus if he plucked singed and cut [with scissors] he is not lashed forty. ${ }^{67}$

As in the Sifre Deuteronomy examples, scripture specifies one item, and a homilist chooses to expand that item into an entire category. In this homily, this very process is disputed: $\mathrm{R}$. Josiah expands the item into a category and R. Jonathan objects. ${ }^{68} \mathrm{R}$. Josiah reads the expansion of 'shaving the head with a razor' into a category of 'actions that cause hair to be cut' in the

64. Cf. Rosen-Zvi, Text, Redaction and Hermeneutic, ch. 4, sects $\mathrm{B}_{\mathrm{I}}$ and $\mathrm{B}_{3}$, who discusses these homilies under the rubric of 'truncating homilies'. Rosen-Zvi believes that this term marks a consciousness of the 'distance between the homily and the simple meaning' of the verse.

65. See M. Kahana, Sifre Ba-midbar, p. II5. Kahana believes that the clause I discuss above is an editorial addition intended to weave together materials from disparate sources.

66. See M. Kahana, Sifre Ba-midbar, p. 230 n. 8 and the references there; Lieberman, Tosefta KiFeshuțah, vol. 7, pp. 544-5.

67. Sifre Num. 25, ed. Kahana, 11. 4-6.

68. The Mishnah ( $m \mathrm{Naz}$. 6:3) follows the opinion of R. Josiah. See also Sifre Zut. Num. 6:I, ed. Horowitz, p. 239. See also above, n. 23. 
general clause at the end of the verse: 'All the days of their nazirite vow no razor shall come upon the head [...] they shall be holy; they shall let the locks of the head grow long.' Being 'holy', synonymous with letting the hair grow long, is read as an expansion of 'no razor shall come upon the head'. Thus it includes other actions which might impede on the general goal of letting the hair grow long. R. Jonathan objects, and likely reads the relationship of the clauses in the opposite way: being 'holy' and letting the hair grow long is impeded most fundamentally by the cutting of the locks with a razor, not in any other way. ${ }^{69} \mathrm{R}$. Josiah, however, needs the second clause of the verse to effect the expansion, a clause missing from the three examples in our text. ${ }^{70}$

\section{Dbr hktwb b-hwwh}

Sometimes, Ishmaelian Midrashim will state that 'scripture spoke regarding things that are', dbr hktwb $b$-hwwh. ${ }^{71}$ This rule is closest to the one from Plutarch quoted above. It is found, for example, in the Mishnah, to explain why oxen and donkeys are mentioned in scripture when the law applies to all animals equally:

Oxen and all livestock are equal regarding falling into pits and being kept away from Sinai, double payments and return of lost property, for unloading, muzzling, mixed species and the Sabbath. And wild animals and birds are like them as well. If so, why does it say ox or donkey (Exod. 21:33)? Rather, scripture spoke regarding things that are. ${ }^{72}$

This method is not implemented here, likely because all the instances of $d b r$ $h k t w b$ b-hwwh are descriptive, while the cases here are prescriptive. ${ }^{73}$

\footnotetext{
69. See also $t$ Nez. $4: 3$.

70. Cf. the discussion of the Bavli's text in M. Kahana, Sifre Ba-midbar, p. 230 n. I3.

7I. For a comprehensive list, see Rosen-Zvi, Text, Redaction and Hermeneutic, ch. 4, Appendix A. Lists of instances are found in Mek. RI kaspa 20, ed. Horowitz-Rabin, pp. 320-2I and Mek. RI pisha 3, ed. Horowitz-Rabin, II. See also mB. Qam. 5:8; Sifre Deut. 255, ed. Finkelstein, p. 280. See Rosen-Zvi, Text, Redaction and Hermeneutic, ch. 4, sect. A. He attempts to distinguish between using the term to 'expand the law', current in the school of R. Ishmael, and its use to 'account for restrictive language in scripture', current in the school of R. Akiva. He asserts that the Akivan 'expansions of the law' are not derived from this rule but from other hermeneutic principles.

72. mB. Qam. 5:8.

73. Mek. RI Pisha 8, ed. Horowitz-Rabin, p. 28, is especially instructive. Compare Sifre Deut. 203, ed. Finkelstein, p. 239, and Midrash Tannaim ad Deut. 20:19. See also the general statement in Baraita de-sheloshim u-shtayim middot, ed. Enelow, p. 3 I.
} 
I return, then, to our tradition. In these three cases, the Ishmaelian method comes up short and the tradition (Halakhah) expands the scope of a noun in the verse without regard for the usual Ishmaelian rules of exegesis. Earth, awl and book become 'all things' that conform to a certain category, similar to the object discussed, by fiat of 'Halakhah'. There is no explicit hint in the verse that these objects should be understood as a class, no particle such as kol or a list of items that might be construed as perat. ${ }^{74}$ Also missing are general statements in other parts of the verse or in parallel verses that might hint that an expansion is in order.

\section{A new meaning of ' $q p$}

This reading requires a different meaning of ' $q p$ : something that could imply that scripture here is not circumvented or bypassed, but rather is augmented or expanded by Halakhah. In keeping with Cana Werman's correct characterization of the function of ' $q p$, I suggest that Rabbi Ishmael is using a different meaning of the verb: 'to increase' or 'to multiply'. Although this meaning of the verb is not attested elsewhere in Hebrew, a study of the usage in Aramaic is relevant.

Jonas Greenfield pointed out that Aramaic ' $q p$ is cognate with the following Semitic roots: ${ }^{75}$

$\begin{array}{llll}\text { Proto-Semitic: } & d^{c} p & \text { Akkadian: } & { }^{c} s p \\ \text { Arabic: } & d^{c} f & \text { Old Aramaic: } & \left({ }^{c} q p\right) \text { ? } \\ \text { South-Semitic: } & d^{c} p & \text { Aramaic: } & { }^{c} p p^{75} \\ \text { Caananite: } & s^{c} p & & \end{array}$

74. On kelal u-ferat, see M. Kahana, 'Kavim le-toledot hitpathutah shel middat kelal u-ferat bi-yeme ha-tannaim', in A. Edrei et al. (eds), Mehkarim ba-Talmud uva-Midrash: sefer zikaron le-Tirtsah Lifshits (Jerusalem: Mossad Bialik, 2005), pp. I73-216; Chernick, 'Formal Development' (above, n. 25). See e.g. Mek RI bahodesh 8, ed. Horowitz-Rabin, p. 43 and Mek. RS ad Exod. 20:I4, ed. Epstein-Melammed, pp. I53-4.

75. J.C. Greenfield, 'Studies in Aramaic Lexicography I', in Sh. M. Paul, 'Al Kanfei Yonah: Collected Studies of Jonas C. Greenfield on Semitic Philology (Leiden: Brill and Jerusalem: Magnes, 200I), pp. 6-2I, esp. p. 8.

76. And, although Greenfield does not list them: " $p$ and ' $w p /{ }^{c} y p$. 
Per Greenfield, just as $\mathrm{BH} s^{c} y p$ is an object that is wrapped around the head, ${ }^{77}$ so too ' $q p$, found in several dialects of Aramaic, means 'to turn' or 'to double over'. As in the examples from Rabbinic Hebrew above, in Targumic Aramaic ' $q p$ is used to denote double-crossing and 'turning' on others. In Genesis 43:18 Joseph's brothers return to Egypt for a second time, after returning home with extra money which was placed in their cargo. They are called to Pharaoh's house and they are scared. Targum Neofiti ad loc. reads: 'and they said: we are being brought [back] because of the matter of the silver which was placed in our cargo, to lord it over us and to $m t^{\text {' }} q p^{\text {' }}$ on us, and to take us as slaves, and our donkeys. ${ }^{78}$ Here ' $q p$ translates MT lhtnpl and likely means 'to turn on us', similar to the wolf who turns on the dog in Sifre Deuteronomy. ${ }^{79}$

But it is not only cloth, or people, who can 'turn' or 'double over'. In a bill from Elephantine (TAD B 4.2), the lender promises that 'If I do not pay you all your money, and its interest, until the month of Thoth in the year 36, your money, and its outstanding interest, will be doubled ( $y^{c} q p$ kspk wmrbyth), and will increase upon me ( $r b h$ ' $l y)$ month by month' (11. 7-9). ${ }^{80} \mathrm{In}$ a financial context, then, ' $q p$ can mean 'double'.

Greenfield placed ' $q p$ in parentheses and noted: 'Although I believe that "will be doubled" is a very likely translation for $y^{\text {c }} q p$ in this text, I have hesitated to remove the lingering doubts indicated by the parenthesis.' Considering the following piece of evidence, however, places this translation on firmer ground. In TAD B3.I, a bill of loan from Elephantine from I3 December 456, the borrower promises: 'if the interest will become equal to the principal, the interest will be like the principal, one to one.' It seems that a similar law is operative in both $\mathrm{B}_{3} . \mathrm{I}$ and $\mathrm{B}_{4} .2$ : in the former, the passage of time activates a clause that doubles the interest, making it equal to the principal, while in the latter both interest and principal double.

77. Gen. 24:65; Gen. 38:14, I9.

78. 'To lord it over us', lmtrbrb' ' $y n$ ', is likely a variant reading of lhtgdl for MT lhtgll. A similar reading is reflected in all Aramaic translations (Peshitta, Onkelos and Geniza Targum D).

79. However, compare Peshitta's Imtnkl( $w$ ) 'In, 'to deceive us', which suggests that ' $q p$ here might mean 'cheat'; see also Tg. Ps.-J. ad loc.

8o. For this translation, see A.E. Cowley, Aramaic Papyri of the Fifth Century B.C. (Oxford: Clarendon Press, 1923), p. 35; B. Porten and A. Yardeni, Textbook of Aramaic Documents from Ancient Egypt (Jerusalem: Hebrew University of Jerusalem, 1986), II, sect. 3.I; Y. Muffs, Studies in the Aramaic Legal Papyri from Elephantine (Leiden: Brill, 2003), p. I84; see also Greenfield, 'Studies in Aramaic Lexicography I', p. 8, n. I4. 
The Eastern Aramaic cognate of the root, with three phonetic variants, ${ }^{c} p$, ' $p p$ and ' $w p,{ }^{81}$ displays a similar range of meanings. In Syriac these roots can connote both 'to double' and 'to multiply'. ${ }^{82}$ In the Peshitta, they are consistently used to translate nouns of the root kpl (e.g. Exod. 26:9, Ezek. I2:I9 and Isa. 40:2). As in Hebrew kpl, 'double' can mean 'twice' as well as 'many times'. A good example is found in Ephrem:

let us look at traders and farmers. Those who do not take out beforehand what they saved make no accrual or profit in their possessions. But it is right for the farmer to take out of his storehouse to sow grain and for the merchant to invest money on merchandise, that which he shall bring in with great profit $\left("{ }^{\prime}{ }^{\prime} s g y^{\prime \prime}\right) \cdot{ }^{83}$

And, in a monetary context:

How multiplied $\left({ }^{c} p\right)$ is the debt (or: interest) even of the debtor / Who owes the principal in envy / A full debt ${ }^{84}$

Or, in the Babylonian Talmud, a story of a sage who sends charity to a man with an ostentatious lifestyle:

There was another poor man to whom [Mar Ukba] would send 400 Zuz every eve of Yom Kippur. One time he sent them with his son. He returned and said: he does not need [the money]. He said: what did you see? He said: I saw that they were sprinkling aged wine before him. [Mar Ukba] said: is he that pampered? He doubled [the money] (' $y p y n h w$ ) and sent it to him. ${ }^{85}$

I propose that $\mathrm{R}$. Ishmael, in our homily, is employing this meaning of 'qp. Although the verse offers a single example, 'awl', 'book' and 'earth/ dust', the law expands this example into a category. It 'multiplies it'. ${ }^{86}$ The preposition ' $l$, in the phrase hlkh 'qpt ' $/$ hmqr' marks $m q r$ ' as the indirect object of hlkh, and denotes an amount 'greater than', as in the phrases $y t y r$

8I. For the semitic etymology, see Greenfield, 'Studies in Aramaic Lexicography I', and M. Sokoloff, A Syriac Lexicon: a Translation from the Latin: Correction, Expansion, and Update of C. Brockelmann's Lexicon Syriacum (Winona Lake IN: Eisenbrauns and Piscataway NJ: Gorgias Press, 2009), p. 8I.

82. See also Drower-Macuch, Mandaic Dictionary, s.v. $A P P$, ' $P P$, 32a: 'a merchant who doubles and redoubles his wealth'.

83. S. Ephraemi Syri, Rabulae episcopi Edesseni, Balaei aliorumque Opera selecta: e codicibus syriacis manuscriptis in museo Britannico et bibliotheca Bodleiana asservatis primus (ed. J.J. Overbeck; Oxford: Clarendon Press, I865), p. IоI, 1. 27 (translation my own).

84. Ephrem, Hymns on Faith, 68:Ir. Ephrem here is playing on the double meaning of hwb', both 'sin' and 'debt'.

85. bKetub. 76 b. See also Gaster, Exempla of the Rabbis, p. 20.

86. See also M. Drower-Macuch, Mandaic Dictionary, s.v. AUP, Iо. 
${ }^{\prime} l, m r w b h{ }^{c} l$ or ${ }^{c} d p{ }^{c} l .^{87}$ A proper translation would be 'the tradition is greater than the verse', or 'the tradition is twice greater than the verse'. This is the usage in TAD B 3.I as well. The borrower promises:

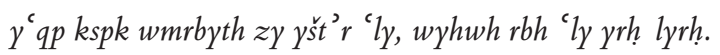

Your money and the outstanding interest will double upon me, and will accumulate upon me month for month.

In both clauses of the sentence, " $l y$ refers back to the verb: just as $r b h " c y$, so $y^{c} q p^{c} l y .{ }^{88}$

This meaning of ' $q p$ is rare, but it accounts perfectly for the relationship between Halakhah and scripture described by Rabbi Ishmael: ${ }^{89}$ the detail in scripture is one, but the accepted tradition, 'Halakhah', rules that it is many things which are derived from that detail, and include that detail. But scripture is not 'uprooted'. Rather, it is enhanced and augmented; 'doubled over'. This is an additional meaning of the root, and does not change the meaning of the other occurrences which I surveyed above. ${ }^{90}$

\section{Conclusion}

In this article I have attempted to offer a more nuanced reading of the phrase hlkh 'qpt 'l hmqr'. Though it is often translated 'Halakhah circumvents (or: uproots) scripture', I have shown that this translation does not accord with the examples offered by the homily. Additionally, although many have used the homily to reflect on the relationship between 'oral' and 'written' laws

87. Yt(y)r'l e.g. mMa'cas. 5:6, mGit. 4:6, mB. Qam. 9:4, mB. Meși 'a 7:5, mMenah. II:9, mArak. 2:I-2, m'Arak. 4:4, mOhal. I2:6, mNeg. 3:8. In the Tosefta, the phrase $y t y r ' l k n$ amrw is used to introduce a tradition that expands a previous tradition; see e.g. tDemai 5:I9-20 and cf. mGit. 3:I.

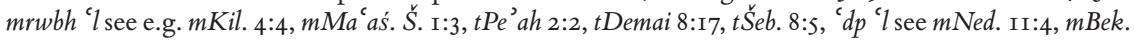

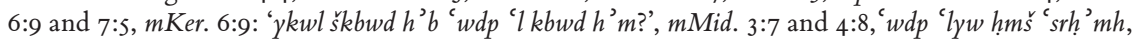
mKelim 4:4, I0:8, mOhal. I2:I and I4:5, Sifre Deut. II9, ed. Finkelstein, p. I43. Cf. also mtqyn ' $l d b r$ twrh, $\gamma \stackrel{S}{S} e b$. 10:3, 93c and $m t n h$ ' $l m h$ s'ktwb btwrh, in $m B$. Bat. 8:5, with C. Hayes, What's Divine about Divine Law?: Early Perspectives (Princeton NJ: Princeton University Press, 20I5), p. 295 n. 2I.

88. In Syriac, the usage ' $q p+{ }^{'} l$ is also attested, albeit rarely. See Peshitta ad Isa. 40:2, 2 Chron. 25:9, Matt. 23:15 and Rev. I8:6.

89. For similar hapaxes, see M. Kahana, 'Ma'alat Yeshivat Erets Isra'el Ba-Mekhilta Lidevarim', Tarbiz, 62 (1993), pp. 50I-I4, esp. pp. 507-8; M. Kister, 'Milim ve-Inyanei Lashon Mi-Tsefunei Midbar Yehudah', Lšonenu, 67:I (2004), pp. 27-44, esp. pp. 38-4I; Sh. Naeh, 'Shetei he'arot la-milon ha-talmudi: al ȘLL ve-al NWL', Leshonenu la-'am 56:I (2007), pp. 43-52.

90. The anonymous reviewer suggested 'wraparound' as a translation for all the occurrences of 'wqpt. I think there is no appropriate English word, although various iterations of 'double' or 'turn' can work for almost all the occurrences, as I indicate in my discussions above. 
or between the Torah and the 'tradition of the fathers', the examples in the homily are all interpretive. Based on a comparison with Aramaic financial terminology, I suggest that the best translation of ' $q p$ ' $a$ l in this homily is 'multiplies' or 'doubles over' scripture. This usage reveals the true meaning of the homily: an internal reflection on interpretive practices within the school of Rabbi Ishmael. In some cases, the practitioners of the Ishmaelian method of reading know what the result of their homily should be, but they do not possess the hermeneutic tools to arrive at the desired result. In these cases they appeal to an accepted reading tradition to guide them to the predetermined reading of the verse. The list of places where 'Halakhah multiplies scripture' does not bear on the question of the existence of a received tradition of unwritten laws in the school of Rabbi Ishmael. It does, however, point to the existence of received reading traditions in this school, at which the practitioner is meant to arrive using hermeneutic tools - except when they cannot produce the desired results.

A PPENDix Hebrew text of Sifre Deuteronomy i22 (ed. Finkelstein, I80)

This text is based on MS Vatican Ebr. 32. The numbers in brackets indicate the order in which it should be read as reproduced in the translation above. Homilies [3] and [4], indented above, are a gloss copied from the Ishmaelian Mekhilta to Deuteronomy, now lost. In MS Vatican it was copied from two segments in the margins of another MS, in the incorrect order, and inserted in two different places in the text. In MS London BL Add. I6406 (cat. Margoulioth 34I) and Yalkut Shimoni MS Oxford Heb.b.6 (cat. Neubauer 2637 , ed. Heiman p. 310) the (incorrect) order of the segments is the same, but units [3b] and [3a] appear together. The text of the glosses is essentially identical in all the witnesses. It is also found in the commentary of R. Hillel b. Eliakim 'from the land of Greece' (ed. Kolidetsky, I948, p. I36; ed. idem, 1983, p. I20). ${ }^{91}$ A similar tradition appears in Midrash Hagadol ad Deut 24:I; see Midrash Tannaim ed. Hoffmann, p. I54. The gloss is missing from MSS Berlin Staatsbibliothek (Preussischer Kulturbesitz) Or. Qu. I594, Oxford Marshall Or. 24 (cat. Neubauer I5I) and ed. princ. (Venice I546). It is also

9I. On the two editions, each based on a different set of textual witnesses, see M.I. Kahana, 'Peirush rabbeinu hillel la-sifrei', Kiryath Sepher 63:I (I990), pp. 27I-80. 
missing from Midrash Hagadol ad loc., and the commentary attributed to Raabad (ed. Basser, I994 and ed. idem, 2009).

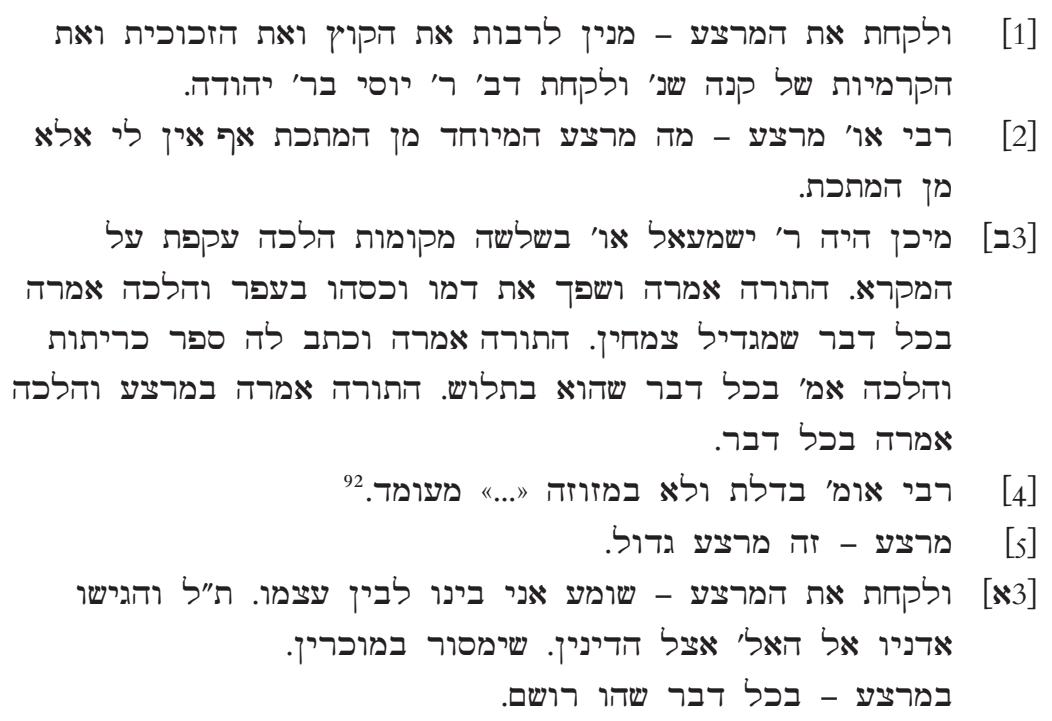

92. Cryptic. The parallel Mek. RS, ed. Epstein-Melammed, p. I6 $3_{14}$ might be a source for the missing text:

רבי אומ' בדלת - ולא במזוזה ״יכול בדלת העומד או בדלת העקור ת"ל או אל המזוזה. מה מזוזה מעומד אף דלתג מערת ולימד.

Something along these lines may have existed in an earlier copy of the Mekhilta to Deuteronomy, now lost. Cf. Mek. RI nezikin 2, ed. Horowitz-Rabin, p. 252, from which R. Hillel ad loc. offers a similar correction. See also Epstein, Mevo ot le-siferut ha-tannaim, p. 559 n. Iог. 